\title{
Müfredata eklenen bir dersin ikinci sınıf tıp öğrencilerinin kadına yönelik şiddetle ilgili bilgi ve tutumlarına etkilerinin değerlendirilmesi
}

\author{
H Aslı Davas Aksana , Işıl Ergina, Hür Hassoyb, Raika Durusoyb, Meltem Çiçeklioğluc
}

Özet

Amaç: $\mathrm{Bu}$ araştırmanın amacı "kadına yönelik şiddete müdahalede sağlık çalışanlarının rolü" uygulama dersini alan Ege Üniversitesi Tıp Fakültesi ikinci sınıf öğrencilerinin ders öncesi ve sonrasındaki bilgi düzeyleri ve tutumlarını ölçmek ve toplumsal cinsiyet rolleri hakkındaki görüşlerini tanımlamaktır. Yöntem: Tıp Fakültesi ikinci sınıfa 334 kişi kayıtlıdır. Kapsayıcılık \%85,6'dır. Ankette kadına yönelik şiddet tanımlarıyla ilgili on soru, hekimin bu konudaki rolüyle ilgili sekiz soru ve toplumsal cinsiyet rolleriyle ilgili 20 soru ve öğrencilerin sosyo demografik özelliklerini sorgulayan sekiz soru yer almaktadır. Bilgi soruları 10 puan üzerinden, profesyonel tutum ve toplumsal cinsiyet rollerine ilişkin sorular ise üçlü Likert ölçeğiyle değerlendirilmiştir. Daha yüksek puan alan öğrenci daha olumlu tutuma sahip kabul edilmiştir. Bulgular: Araştırma grubunun \%39,9’u kadındır. \% 41,9’u Fen lisesi, \%36,5'i Anadolu lisesi ve \%\%10,8'i özel lise mezunudur. \%45,1 Ege Bölgesi doğumludur. Öğrencilerin \%15,2'si ailesinde şiddete tanık olduğunu belirtmiştir. Ön test bilgi puan ortalaması $6,8 \pm 1,8$ iken son test sonuçları $9,1 \pm 1,4(t=-22,923$, $\mathrm{p}=0,001$ )olarak saptanmıştır. Ders öncesi profesyonel tutum toplam puanı ortalaması $19,7 \pm 2,4$, ders sonrası da 21,1 $\pm 2,3$ olmuştur( $\mathrm{t}=9,877 \mathrm{p}=0,001)$. Toplumsal cinsiyet rolleri ön test toplam puanı $47,2 \pm 7,4$ son test toplam puanı ise $48,4 \pm 6,4$ olarak saptanmıştır( $t=3,577, p=0,001)$. Hem bilgi hem de profesyonel tutum ve toplumsal cinsiyet rolleriyle ilgili ön-test puan ortalamaları erkeklerin, doğduğu bölge İç Anadolu, Doğu Anadolu ve Güneydoğu Anadolu olanların, anne eğitimi ortaokul ve altı düzeyinde olanların daha düşüktür. Sonuç: $\mathrm{Bu}$ araştırmada, uzun erimdeki etkiler değerlendirilememiş olsa da, Tıp fakültesi ikinci sınıf müfredatına eklenen bu dersin, öğrencilerin hem kadına yönelik şiddetle, hem de bu konudaki gelecekteki rolleriyle ilgili bilgi ve tutumlarının geliştirilmesi açısından önemli olduğu ortaya konmuştur.

Anahtar Kelimeler: Kadına yönelik şiddet, tıp eğitimi, bilgi, tutum, toplumsal cinsiyet rolleri

aÖğr. Grv. Dr. Ege Üniversitesi Tıp Fakültesi Halk Sağlığı AD, İzmir

aÖğr. Grv. Dr . Ege Üniversitesi Tıp Fakültesi Halk Sağlığı AD, İzmir

bUzm. Dr. Ege Üniversitesi Tıp Fakültesi Halk Sağlığı AD, İzmir

bUzm. Dr. Ege Üniversitesi Tıp Fakültesi Halk Sağlığı AD, İzmir

cDoç. Dr. Ege Üniversitesi Tıp Fakültesi Halk Sağlığı AD , İzmir

Sorumlu Yazar: H Aslı Davas Aksan, Ege Üniversitesi Tıp Fakültesi Halk Sağlığı AD 35100

Bornova,İzmir $\quad$ Tel: 2323902078 E-posta: asli.davas@ege.edu.tr 


\title{
An evaluation of the effects on the knowledge and behavior of second year medical school students of a course on violence against women added to their curriculum
}

\begin{abstract}
Objective: The purpose of this study was to measure the pre and post course level of knowledge, attitudes and opinions of second year medical students regarding violence against women, gender roles and of the physician's role for intervention, in relation to a course entitled "the role of health care professionals in intervention concerning violence against women". Method: 334 students were registered in the second year at this Medical School. The participation rate was 85,6\%. The questionnaire included four sections: ten questions related to the definitions of violence against women; eight questions related to the role of physicians in intervention; and 20 questions were associated with gender roles; in addition there were eight questions on socio-demographic features of the students. The questions concerning knowledge were assessed on a scale of one to ten, the questions regarding professional attitude and gender roles were evaluated by a three point Likert scale. The students with higher points were regarded as having more positive attitudes. Results: $39,9 \%$ of the research group were female. $41.9 \%$ of them were graduates of a Science High School, $36,5 \%$ of them were from an Anatolian High School and 10,8\% of them were Private High School graduates. $45,1 \%$ of the respondents were from the Aegean Region of Turkey. 15,2\% of the students stated that they witnessed violence in their family lives. Whilst the precourse knowledge score average was $6,8 \pm 1,8$, the outcomes of post course assessment were $9,1 \pm 1,4(t=-22,923, p=0,001)$. The mean of the pretest professional attitude total score was $19,7 \pm 2,4$, and the post-test $t$ was $21,1 \pm 2,3(\mathrm{t}=9,877 \mathrm{p}=0,001)$. The mean pretest total score for gender roles was $47,2 \pm 7,4$ whereas it was $48,4 \pm 6,4$ posttest $(t=3,577, p=0,001)$. The pre-test means related to knowledge, professional attitude and gender roles were lower for those from Central Anatolia, Eastern Anatolia and Southern Anatolia, for male students and for those whose mothers' educational levels were secondary school or less. Conclusion: Although the study's long term effects could not be evaluated, this research revealed the importance of developing knowledge, attitudes and future roles of second year medical school students by adding a course about violence against women.
\end{abstract}

Key Words: Violence against women, medical education, knowledge, attitude, gender roles

\section{Giriş}

“Türkiye'de Kadına Yönelik Aile içi Şiddet Araştırması" sonuçlarına göre, yaşamlarının herhangi bir döneminde kadınların fiziksel şiddete maruz kalma sıklığı $\%$ 39'dur. Bu oran boşanmış ya da ayrı yaşayan kadınlarda \% 73'lere çıkmaktadır¹. Sağlık çalışanları, çoğu zaman şiddet görmüş kişilerin aile dışına çıktıklarında tek görüşebildikleri dolayısıyla tek yardım alabilecekleri kişilerdir. Aile içi şiddet kurbanlarının yaklaşık \%43 kadarının ilk yardım talep ettikleri kurumun sağlık kurumları olduğu bildirilmektedir².

Fiziksel, cinsel ve psikolojik şiddet gören kurbanlar çok çeşitli sağlık sorunlarıyla sağlık kurumlarına başvururlar. Şiddet gören kadınların hem fiziksel hem de ruhsal sağlık durumlarının görmeyenlere göre daha kötü olduğu ve sağlık hizmetlerini daha fazla 
kullandığ araștırmalarda gösterilmiștir.3,4,5 Sağlık çalışanlarının şiddetin önlenmesindeki rolleri özetle şiddet görmüş vakaları tanımak, onların sağlık sorunlarını çözmek, yasal hakları konusunda bilgilendirmek ve ulaşabileceği sosyal kurumlarla iletişim kurmasına yardımci olmak olarak sıralanabilir. Gerçekten de yapılan araștırmalar; hastane acil servislerinde tedavi edilen her dokuz kadından birinin, ayaktan tedavi veren kurumların acil servislerinde muayene edilen her yedi kadından birinin, her beș gebeden birinin, istismar nedeniyle başvuran çocukların yarısının annesinin, intihar girişiminde bulunan her üç kadından birinin ve psikiyatri hastalarının \%40-70'inin aile içi şiddet kurbanı olduğunu göstermektedir. ${ }^{6}$ En önemlisi ise araştırmaların kadınların destekleyici ve güvenli bir ortamda, şiddet deneyimleri hakkında konuşmak istediklerini göstermesidir.7

Sağlık çalışanından kaynaklı engellerin başında aile içi şiddetin tıp eğitimi müfredatına yeni girmesi, dolayısıyla sağlık çalışanlarının bu konudaki bilgisizliği gelmektedir. Özellikle aile içi şiddetin üreme sağlığı ve olası diğer sağlık sorunlarına yol açma potansiyeli, çalışanlar tarafından bilinmemektedir 5,6,7. Vakaların çoğunun histeri tanısı konulup gönderilmesi ve gerçek sorunla ilgili müdahalede bulunulmaması, sağlık hizmetlerinin verimsiz kullanımına neden olmaktadır6. Aynı şekilde aile planlaması konusunda dirençli vakalarda şiddet sorgulanmalıdır. Şiddet gören kadınların cinsel otonomileri sıklıkla zayıftır bu nedenle cinsel yolla bulaşan hastalıklar ve istenmeyen gebeliklerin önlenmesi bu kadınlarda daha önemli hale gelmektedir $5,6,8,9,10$.

Sağlık çalışanlarının bu alanda profesyonel yaklaşım geliştirmelerini sağlayacak eğitimleri genellikle yoktur ${ }^{10}$. İzmir'de yürütülen bir araştırmada, bir üniversite acil servisinde çalışmakta olan hekim ve hemşirelerin yaşadıkları toplumdakine benzer oranlarda șiddeti onaylayabildikleri gösterilmiştir ${ }^{11}$. Türkiye'de tıp fakültesi öğrencileri üzerinde yapılan bir çalışmada da, öğrencilerin \%68,3'ü annelerinin fiziksel ve sözel şiddete maruz kaldıklarını ifade etmişlerdir. ${ }^{12}$

3 Şubat 2009 tarih 2009/14 sayll genelge ile Sağlık Bakanlığı tarafindan başlatılan "Kadına Yönelik Aile İçi Şiddetle Mücadelede Sağlık Personelinin Rolü ve Uygulanacak Prosedürler" konulu eğitim kapsamında, birinci basamakta ve hastanelerin acil servislerinde görev yapmakta olan ebe, hemşire, aile sağlığ elemanı, sağlık memuru ve hekimler, bu konuda eğitim almaya başlamışlardır. Bununla birlikte sağlık çalışanlarının lisans eğitiminde bu konuya yeterince yer verilmemektedir. Kanada'da 222 diş hekimliği, tıp ve hemşirelik eğitim programının değerlendirildiği bir araştırmada, tıp fakültelerinin sadece \%43'ünde kadına yönelik şiddetle ilgili bir eğitim verildiği tespit edilmiştir ${ }^{13}$. Verilen eğitimlerin etkinliğine dair de az sayıda çalışma bulunmaktadır ${ }^{14}$.

$\mathrm{Bu}$ araştırmada Ege Üniversitesi Tıp Fakültesi ikinci sınıf öğrencilerinin kadına yönelik şiddet ve bu konudaki rolleriyle ilgili bilgi ve tutumları, müfredata eklenen dersin öncesi ve sonrasında ölçülerek eğitimin etkinliğinin değerlendirilmesi amaçlanmıștır.

\section{Yöntem}

Tıp Fakültesi ikinci sınıfa 2010-2011 eğitim döneminde 334 kişi kayıt yaptırmıștır. 21 kişiye derse girmediği, 27 kişi de anketi doldurmadığı için araştırmaya dahil edilmemiştir. Kapsayıcılık \%85,6'dır. EÜTF topluma yönelik öğrenim hedeflerini içeren eğitim programının sistem bazında entegrasyon çalışmaları 2003-2004 öğretim yılında uygulanmaya başlamıştır. EÜTF eğitim programının ilk üç yılı dört evreye ayrılmıştır. İlk iki yılda Temel tıp bilimlerine giriş(Evre 1E1), sistemler bazında normal yapı ve fonksiyon (Evre 2-E2), patolojilere giriş 
(Evre3-E3) tamamlanmakta, üçüncü yll ise sistem bazında patolojiler (Evre 4-E4) yer almaktadır. Hem E2, hem de E4'te yer alan sistem gruplarından biri de "Hayatın Evreleri”dir. Toplum Sağlığı ve Alan (TSA) uygulamaları dikey koridor olarak programa, sistemler bazında entegre edilmiştir. "Kadına yönelik şiddete müdahalede sağlık çalışanlarının rolleri” uygulamalı dersi, ikinci sinıf birinci döneminde yer alan E2B4 Bloğunda entegre olarak yürütülen TSA uygulamalarından biridir. Bu Bloktaki diğer TSA uygulamalarının başlıkları; "üreme sağlığı ve üreme hakkı", "gebe- bebek izlemi"dir. Bu blok kapsamında hayatın çeşitli evrelerindeki(bebek, çocuk, genç, yaşlı) normal yapı ve fonksiyona dair bilgilendirmeler yanı sıra çocuk istismarı, gençlerin sağlık sorunları ve kişilik gelişimi ve yetişkin davranışı gibi başlıklar da farklı Anabilim dallarinca teorik olarak aktarılmaktadır. TSA'nın bu bloktaki teorik dersleri ise; toplumu tanıma, toplum tabanlı sağlık hizmeti, ekip hizmeti, sağlık ölçütleri ve güvenli anneliktir.

\section{Ders-müdahale}

İki saatlik "kadına yönelik şiddet" teorik dersinin ardından, öğrenciler 30-35 kişilik 10 gruba ayrılmış, her bir grupla ikişer saatlik "Kadına yönelik şiddete müdahalede sağlık çalışanlarının rolleri" uygulama dersi yapılmıștır. Toplam on uygulama dört eğitici tarafından yürütülmüştür. $\mathrm{Bu}$ derste öğrencilere bir olgu verilmiş, sınıf beş gruba bölünmüş ve her bir gruba bir tartışma sorusu dağıtılmıştır. Yirmi dakikalık bir grup çalışmasından sonra yanıtlarını sınıfla paylaşmaları istenmiş ve soru tüm sınıfla yeniden tartışılmıştır. Grup çalışmasında kullanılan sorular, "Olgunun maruz kaldığı şiddet tipleri nelerdir? Örneklerle açlklayınız."; "Olgunun durumunu ağırlaștıran, bireysel, politik, sosyal, yasal, kültürel, ekonomik risk etmenleri nelerdir?";"Olgunun bu durumdan kurtulmak için nasıl bir desteğe ihtiyacı var?";"Olguya uygun şekilde müdahale etmenizin önündeki engeller neler olabilir?" şeklindedir.

Tartışmada hem kadının sosyoekonomik ve kültürel statüsünün toplumda yükseltilmesinin şiddetin önlenmesi açısından önemi hem de polisteki ilk başvuru, sağlık merkezlerinin uygun hizmeti sunumu, adalet sisteminin kadını koruyacak şekilde yapılandırılması, sığınma evi ve danışma merkezleri gibi kurumlara erişimin kolaylaştırılması gibi başlıklara yer verilmiștir. Geleceğin hekimlerinin pratik hayatlarında böyle bir olguyla karşılaştıklarında sorunu çözmek için bu yaklaşımları göz önünde bulundurmaları gerektiği ve bu konudaki sorumlulukları vurgulanmıștır. Anket" bașlıklı bu dersin başında ve sonunda uygulanmıştır. Öntest ve sosyo demografik soruların yer aldığı anket, dersin başında dağıtılmış, her öğrencinin ankette kendisini bir rumuzla tanitması ve dersin sonunda dağıtılan son testte de aynı rumuzu kullanması istenmiştir.

Kadına yönelik şiddetin tanımıyla ilgili on bilgi sorusu hazırlanmıştır. Doğru yanıtlara bir puan, yanlış yanıtlara 0 puan verilerek toplam on puan üzerinden değerlendirilmiştir. Hekimin bu konudaki rolüyle ilgili literatürden yararlanılarak sekiz soru hazırlanmış ve üçlü likertle değerlendirilmiştir. Daha yüksek puan alan ögrrenci daha olumlu tutuma sahip kabul edilmiștir. TNSA 2008'den yararlanarak da şiddetin gerekçelendirmesiyle ilgili beş önerme yazılmış ve üçlü likertle (1=katılıyorum, 2=kısmen katılıyorum, 3= katılmıyorum) değerlendirilmiştir.

Toplumsal cinsiyet rolleriyle ilgili İmamoğlu(12) tarafından 1995 yılında üniversite öğrencileriyle çalışarak (Cronbach alfa değeri 85, p<0,05)) geliştirdiği ölçekten yararlanılarak 20 önerme hazırlanmıștır. Bu önermelere verilen toplam puan 1=katılıyorum, 2=kısmen katılıyorum, 3= katılmıyorum üzerinden hesaplanmıștır. Puan ne kadar yüksekse toplumsal cinsiyet 
rolleriyle ilgili tutumlar geleneksel tutumlardan uzaklaşmakta ve olumlu olarak değerlendirilmektedir. $\mathrm{T}$ testi analizlerinde, toplumsal cinsiyet rolleriyle ilgili toplam puan ortalamasının altında kalanlar olumsuz tutuma sahip, ortalamanın üzerindekiler de olumlu tutuma sahip olarak kabul edilmişlerdir. Ayrıca öğrencilerin sosyo demografik özellikleriyle ilgili dokuz soru yer almaktadır. Analizlerde; tanımlayıcı ölçütlerden frekans, yüzde, önemlilik testlerinden de bağımlı ve bağımsız gruplarda t-testi uygulanmıştır. $\mathrm{P}<0,05$ anlamlılık düzeyi olarak kabul edilmiştir.

\section{Bulgular}

Araştırma grubunun \%39,9'u kadındır. \%45,1'i Ege, \%12,5'i Güneydoğu Anadolu, \%12,5’i İç Anadolu bölgesi doğumludur. Grubun ve ebeveynlerinin eğitim ve çalıșma durumuyla ilgili değișkenler Tablo 1'de sunulmuştur.

Tablo 1. Araștırma grubunun ve ebeveynlerinin eğitim ve çalıșma durumu

\begin{tabular}{|c|c|c|}
\hline Mezun olunan okul tipi (n=277) & Sayı & $\%$ \\
\hline Fen lisesi & 116 & 41,9 \\
\hline Anadolu lisesi & 101 & 36,5 \\
\hline Özel lise & 30 & 10,8 \\
\hline Anadolu öğretmen lisesi & 22 & 7,9 \\
\hline Devlet lisesi & 8 & 2,9 \\
\hline \multicolumn{3}{|l|}{ Anne eğitim (n=285) } \\
\hline Okur yazar degil & 13 & 4,6 \\
\hline Okur yazar & 12 & 4,2 \\
\hline İlkogretim & 47 & 16,5 \\
\hline Ortaokul & 11 & 3,9 \\
\hline Lise & 80 & 28,1 \\
\hline Üniversite & 111 & 38,9 \\
\hline Lisanüstü & 11 & 3,9 \\
\hline \multicolumn{3}{|l|}{ Baba eğitimi(n=285) } \\
\hline OY & 4 & 1,4 \\
\hline İlkogretim & 24 & 8,4 \\
\hline Ortaokul & 18 & 6,3 \\
\hline Lise & 59 & 20,7 \\
\hline Üniversite & 157 & 55,1 \\
\hline Lisanüstü & 23 & 8,1 \\
\hline \multicolumn{3}{|l|}{ Anne iș $(n=283)$} \\
\hline Çalıșmıyor-evhanımı & 149 & 52,7 \\
\hline Kamuda çalıșan memur & 63 & 22,3 \\
\hline Emekli & 46 & 16,3 \\
\hline Kendi işinde çalışan serbest meslek sahibi & 8 & 2,8 \\
\hline Kamuda çalışan işçi & 6 & 2,1 \\
\hline Diğer & 11 & 3,9 \\
\hline \multicolumn{3}{|l|}{ Baba iş $(n=283)$} \\
\hline Kamuda çalışan memur & 104 & 36,7 \\
\hline Emekli & 70 & 24,7 \\
\hline Kendi işinde çalışan serbest meslek sahibi & 38 & 13,4 \\
\hline Kamuda çalışan işçi & 16 & 5,7 \\
\hline Özel sektörde çalışan işçi & 16 & 5,7 \\
\hline İşçi çalıștıran serbest meslek sahibi & 11 & 3,9 \\
\hline Diğer & 28 & 9,9 \\
\hline
\end{tabular}


Öğrencilerin \%15,2'si ailesinde șiddete tanık olduğunu belirtmiştir. Kadına yönelik șiddetle ilgili ön test ve son testteki doğru yanıtların dağılımı Tablo 2'de sunulmuştur.

Tablo 2. Kadına yönelik şiddet bilgi sorularında kurs öncesi ve kurs sonrası değerlendirmede doğru yanıtların dağılımı (\%)

\begin{tabular}{lcc}
\hline & $\begin{array}{c}\text { Doğru } \\
\text { öntest }\end{array}$ & $\begin{array}{c}\text { Doğru } \\
\text { sontest }\end{array}$ \\
\hline $\begin{array}{l}\text { 1-Eşinin kadına sadece istediği zaman para vermesi ekonomik bir } \\
\text { şiddettir }\end{array}$ & 82,5 & 93,8 \\
2-Kadına yönelik şiddeti hekimin polise bildirim zorunluluğu vardır & 71,8 & 91,0 \\
3-Kadının sokağa yalnız başına çıkmaması ona uygulanan bir şiddettir. & 82,4 & 93,1 \\
4-Kadının oje sürmesine izin vermeme bir şiddettir. & 75,0 & 84,8 \\
5-Kadının eteğinin boyuna karışma bir şiddettir. & 64,9 & 79,7 \\
6-Eşinin kadınla isteği dışında birlikte olmasıs tecavüzdür. & 90,4 & 96,7 \\
7-Kadına yönelik şiddetle ilgili acil servislerde ayrı bir form & 68,4 & 90,8 \\
doldurulması gerekmektedir. & & \\
8-Sadece yoksul ve eğitimsiz kadınlar şiddet görürler & 96,1 & 96,3 \\
9-Ebeler ve birinci basamak hekimleri şiddet görmüş kadınla en sık & 60,4 & 93,1 \\
karşlaşan sağlık personelidir. & 75,7 & 90,9 \\
10-Gebe kalmak kadını șiddetten korur & & \\
\hline
\end{tabular}

Ön test bilgi puan ortalaması $6,8 \pm 1,8$ iken son test sonuçları $9,1 \pm 1,4(t=-22,923$, $\mathrm{p}=0,001$ )olarak saptanmiştır. Son testte yanlıștan doğruya en fazla oranda değișen sorular; "Ebeler ve birinci basamak hekimleri şiddet görmüş kadınla en sık karşılaşan sağlık personelidir" (\%32,7), "Kadına yönelik şiddetle ilgili acil servislerde ayrı bir form doldurulması gerekmektedir" $(\% \quad 22,4)$, Kadına yönelik şiddeti hekimin polise bildirim zorunluluğu vardır" $(\% 19,2)$ olmuştur.

Ön testte kadınların bilgi puanı ortalaması 7,5 $\pm 1,3$; erkeklerinse $6,3 \pm 1,9$ olarak bulunmuștur( $\mathrm{t}=5,914 \mathrm{p}=0,001)$. Anne eğitimi ortaokul ve altı olanların $(t=4,455$, $\mathrm{p}=0,001)$, annesi ev hanımı olanların ( $\mathrm{t}=3,006$ $p=0,003)$, baba eğitimi ortaokul ve altı olanların $(t=2,805, p=0,005)$, doğduğu bölge
İç Anadolu, Doğu Anadolu ve Güneydoğu Anadolu olanlarm $(t=4,099, p=0,001)$ bilgi puanları anlamlı olarak düșük saptanmıștır. Babanın işi ve aile içi şiddete tanık olmayla ön test bilgi puanları arasında ilişki saptanmamıştır.

Son testte de tüm puanlar yükselse de, erkeklerin $(\mathrm{t}=232,467, \mathrm{p}=0,001)$; anne eğitimi ortaokul ve altı olanların $(\mathrm{t}=2,304$, $\mathrm{p}=0,02)$; doğduğu bölge İç Anadolu, Doğu Anadolu ve Güneydoğu Anadolu olanların $(\mathrm{t}=116,540, \mathrm{p}=0,004)$ bilgi puanları düşük saptanmıștır. Baba eğitiminin ve annenin ev hanımı olmasının bilgi puanına etkisi son testte kaybolmuştur( $(\mathrm{p}>0,05)$. Tablo3'te öğrencilerin şiddet görmüş bir kadına yardım konusunda kendi rolleriyle ilgili görüşleri değerlendirilmiștir. 
Tablo 3. Araştırma grubunun sağlık çalışanlarının kadına yönelik şiddete müdahaledeki öncesi ve sonrası değerlendirmede dağılımı (\%)

\begin{tabular}{|c|c|c|c|c|c|c|}
\hline & \multicolumn{2}{|c|}{ Katıllyorum } & \multicolumn{2}{|c|}{$\begin{array}{c}\text { Kismen } \\
\text { katıliyorum }\end{array}$} & \multicolumn{2}{|c|}{ Katılmıyorum } \\
\hline & Ön & Son & Ön & Son & Ön & Son \\
\hline $\begin{array}{l}\text { 1.Dayak yiyen kadınlar mutlaka profesyonel } \\
\text { tıbbi yardım almalıdır }\end{array}$ & 74,4 & 91,3 & 24,9 & 6,9 & 0,7 & 1,8 \\
\hline $\begin{array}{l}\text { 2.İstismara uğramış bir kadına sağlık } \\
\text { personeli yardım edemez, çünkü kadın yine } \\
\text { aynı ortama dönecek. }\end{array}$ & 16,1 & 7,2 & 42,9 & 36,2 & 41,1 & 56,5 \\
\hline $\begin{array}{l}\text { 3.Kadın istismarı çok özel bir konudur, soru } \\
\text { sormak hastayı utandırabilir }\end{array}$ & 26,7 & 25,6 & 44,2 & 32,9 & 29,1 & 41,5 \\
\hline $\begin{array}{l}\text { 4.Hekim ya da hemşire aile içi şiddete } \\
\text { müdahale ederek özel aile işlerine karışmış } \\
\text { olur. }\end{array}$ & 6,6 & 6,5 & 23,8 & 13,0 & 69,6 & 80,5 \\
\hline $\begin{array}{l}\text { 5.Sağllk personeli kadına yönelik şiddete nasıl } \\
\text { müdahale etmesi gerektiği } \\
\text { mutlaka eğitim almalıdır. }\end{array}$ & 91,6 & 97,8 & 6,3 & 0,7 & 2,1 & 1,4 \\
\hline $\begin{array}{lll}\text { 6.Şiddete uğramış kadına öncelikle "eşini } & \text { kack } \\
\text { kızdıracak ne } & \text { yaptığı"nın sorulması } \\
\text { gerekmektedir } & & \end{array}$ & 10,1 & 7,2 & 32,2 & 21,0 & 57,7 & 71,7 \\
\hline $\begin{array}{l}\text { 7.Şiddete uğradığını bildiren kadının doğru } \\
\text { söyleyip söylemediği, kadın eşiyle birlikte } \\
\text { dinlenerek anlașılabilir }\end{array}$ & 21,2 & 10,9 & 44,5 & 26,6 & 34,3 & 62,4 \\
\hline $\begin{array}{l}\text { 8.Şiddete uğramış kadına, tartışmaya yol açan } \\
\text { davranışlarda bulunmamasını önererek } \\
\text { yardımcı olunabilir }\end{array}$ & 7,7 & 6,1 & 35,1 & 19,9 & 57,2 & 74,0 \\
\hline
\end{tabular}

Tablo 4'de öğrencilerin toplumsal cinsiyet rolleriyle ilgili tutumlarının ön ve son testteki dağılımları sunulmuştur. Ders öncesi profesyonel tutum toplam puanı ortalaması $19,7 \pm 2,4$, ders sonrası da $21,1 \pm 2,3$ olmuştur ve aradaki fark istatistiksel olarak $(\mathrm{t}=9,877$ $\mathrm{p}=0,001$ ) anlamlıdır.

Ön testte erkeklerin $(\mathrm{t}=4,327$, $\mathrm{p}=0,001)$, doğum bölgesi İç Anadolu, Doğu Anadolu ve Güneydoğu Anadolu olanların $(\mathrm{t}=2,261, \mathrm{p}=0,025)$ anne eğitimi ortaokul ve altı olanların ( $t=3,024, \mathrm{p}=0,003)$ ve annesi ev hanımı olanların $(\mathrm{t}=3,006 \quad \mathrm{p}=0,001)$ profesyonel tutum puanı daha düşüktür. Baba eğitiminin ve aile de şiddet tanıklığının tutum ön test puanlarına etkisi yoktur( $\mathrm{p}>0,05)$.
Son testte erkeklerin $(\mathrm{t}=4,944$, $\mathrm{p}=0,001)$, doğum bölgesi İç Anadolu, Doğu Anadolu ve Güneydoğu Anadolu olanların $(t=2,428, p=0,016)$ tutum son test puanları hala istatistiksel olarak anlamlı olmakla birlikte anne eğitimi ve annenin ev hanımı olmasının tutum puanlarına olan etkisi kaybolmuştur( $\mathrm{p}>0,05)$.

Üç'lü likert skalası (katılmıyorum, kısmen katılıyorum ve katılıyorum) ile değerlendirilen beş önermeye, öğrencilerin belirtilen bazı durumlarda kadınların fiziksel şiddeti hak ettiği ifadesine puan vermesi istenmiştir. Öğrencilerin, \%38,1'i "Aldatmak", $\% 17,7$ 'si "Çocuklarla iyi ilgilenmemek" \%12,0’ı "Parayı lüzumsuz yere harcamak", \% 11,2 'si "Ailesinin istemediği biriyle evlenmek 
için kaçmak", \%7,6'sı "Cinsel ilişsiyi red etmek", önermelerine ön testte katılıyorum ya da kısmen katılıyorum yanıtı vermişken bu oranlar son testte sirasiyla \%34,1, \%17,1, $\% 8,2, \% 10,8, \% 7,1$ olmuştur.

Tablo 4. Araştırma grubunun toplumsal cinsiyet rolleriyle ilgili görüşlerinin ön ve son testteki dağılımları (\%)

\begin{tabular}{|c|c|c|c|c|c|c|}
\hline & \multicolumn{2}{|c|}{ Katılıyorum } & \multicolumn{2}{|c|}{$\begin{array}{c}\text { Kismen } \\
\text { katıliyorum }\end{array}$} & \multicolumn{2}{|c|}{ Katılmiyorum } \\
\hline & $\begin{array}{l}\text { Ön } \\
\text { test }\end{array}$ & $\begin{array}{l}\text { Son } \\
\text { test }\end{array}$ & $\begin{array}{l}\text { Ön } \\
\text { test }\end{array}$ & $\begin{array}{l}\text { Son } \\
\text { test }\end{array}$ & $\begin{array}{l}\text { Ön } \\
\text { test }\end{array}$ & $\begin{array}{l}\text { Son } \\
\text { test }\end{array}$ \\
\hline $\begin{array}{l}\text { 1.Toplumsal düzen açısından kadının erkek } \\
\text { tarafından sahiplenilmesinde yarar vardır }\end{array}$ & 36,7 & 29,4 & 45,6 & 36,6 & 17,7 & 34,1 \\
\hline $\begin{array}{l}\text { 2.Kadının kocasından çekinmesinde ve } \\
\text { korkmasında yarar vardır }\end{array}$ & 3,9 & 2,9 & 23,2 & 16,1 & 72,9 & 81,1 \\
\hline $\begin{array}{l}\text { 3.Kadın her ne kadar okumuş olursa olsun, } \\
\text { kadınlığını bilmeli, kocasına hizmette kusur } \\
\text { etmemelidir }\end{array}$ & 8,5 & 7,5 & 24,7 & 17,6 & 66,8 & 74,9 \\
\hline 4.Bir erkek kadından daha fazla kazanmalıdır & 14,9 & 12,8 & 23,8 & 18,1 & 61,4 & 69,0 \\
\hline 5.Kadın analık görevini iyi yapmalıdır & 84,1 & 77,8 & 13,4 & 16,8 & 2,5 & 5,4 \\
\hline $\begin{array}{l}\text { 6.Erkek duygu ve düşüncelerini özellikle zayıf } \\
\text { yanlarını belli etmemelidir }\end{array}$ & 8,1 & 9,7 & 23,6 & 17,9 & 68,3 & 72,4 \\
\hline 7.Erkekler kadından daha güçlüdür, & 27,4 & 24,6 & 36,7 & 32,5 & 35,9 & 42,9 \\
\hline 8.Kadının kocasını kıskanması doğaldır & 49,3 & 44,0 & 38,7 & 36,5 & 12,1 & 19,5 \\
\hline $\begin{array}{l}\text { 9.Erkek tek başına kendine bakamaz, bu } \\
\text { nedenle kadının bakımına gereksinim duyar }\end{array}$ & 18,1 & 14,0 & 34,8 & 29,9 & 47,2 & 56,1 \\
\hline $\begin{array}{l}\text { 10.Kadını kendi başına bırakılmamalı, diğer } \\
\text { cins ile ilişkiler erkekte hoş görülebilir ama } \\
\text { kadını lekeler }\end{array}$ & 7,4 & 5,4 & 15,2 & 14,0 & 77,3 & 80,6 \\
\hline 11.Erkeğin hükmettiği evde mutluluk olmaz & 22,3 & 31,5 & 38,5 & 28,0 & 39,2 & 40,5 \\
\hline $\begin{array}{l}\text { 12.Günümüzde kadın ve erkek ev işlerini } \\
\text { paylaşmalıdır }\end{array}$ & 75,1 & 79,6 & 21,0 & 17,9 & 3,9 & 2,5 \\
\hline 13.Kadın hakları hareketini destekliyorum & 71,7 & 77,1 & 21,9 & 18,3 & 6,4 & 4,7 \\
\hline $\begin{array}{l}\text { 14.Günümüzde her ne kadar kadın ve erkek } \\
\text { eşit kabul edilse de tam bir eşitlik söz konusu } \\
\text { olamaz }\end{array}$ & 44,7 & 32,9 & 35,8 & 41,1 & 19,5 & 26,1 \\
\hline $\begin{array}{l}\text { 15.Kadın hakları savunucularının ne yapmak } \\
\text { istediklerini anlayamıorum }\end{array}$ & 8,3 & 5,4 & 25,3 & 22,5 & 66,4 & 72,1 \\
\hline $\begin{array}{l}\text { 16.Kadın evliliğinde aradığını bulamasa da } \\
\text { sabretmesini bilmelidir }\end{array}$ & 7,9 & 7,2 & 34,6 & 23,7 & 57,5 & 69,2 \\
\hline $\begin{array}{l}\text { 17.Kadın ve erkek ilişkisi birinin reis olmasını } \\
\text { gerektirmeyen türde bir ilișkidir }\end{array}$ & 64,9 & 71,9 & 20,2 & 13,2 & 14,9 & 14,9 \\
\hline $\begin{array}{l}\text { 18.Kız da erkek de evlattır, ancak erkek evlat } \\
\text { sahibi olmak daha önemlidir }\end{array}$ & 3,5 & 6,5 & 6,4 & 5,4 & 90,1 & 88,1 \\
\hline 19.Eğitim erkekler için daha önemlidir & 8,9 & 9,0 & 12,1 & 11,1 & 79,1 & 79,9 \\
\hline $\begin{array}{l}\text { 20.Erkeklerin daha avantajlı bir konumda olması } \\
\text { doğal değil, toplumsal düzenin bir sonucudur }\end{array}$ & 55,1 & 57,3 & 33,9 & 31,9 & 11,0 & 10,8 \\
\hline
\end{tabular}


Toplumsal cinsiyet ön test toplam puanı $47,2 \pm 7,4$, son test toplam puanı ise $48,4 \pm 6,4$ olarak saptanmıştır. Aradaki fark istatistiksel olarak anlamlıdir $(\mathrm{t}=3,577$, $\mathrm{p}=0,001)$. Ön-testte toplumsal cinsiyet puanları erkeklerde $(t=7,639, p=0,001)$, doğum bölgesi İç Anadolu, Doğu Anadolu ve Güneydoğu Anadolu olanlarda $(t=3,376$, $\mathrm{p}=0,001)$, anne eğitimi ortaokul ve altı olanlarda $(t=5,124, p=0,001)$, baba eğitimi ortaokul ve altı olanlarda $(\mathrm{t}=2,519, \mathrm{p}=0,012$, annesi ev hanımı olanlarda $(t=3,732 \mathrm{p}=0,001)$ daha düşüktür. Son testte de erkeklerin $(\mathrm{t}=8,691, \mathrm{p}=0,001)$, doğum bölgesi İç Anadolu, Doğu Anadolu ve Güneydoğu Anadolu olanların $(t=3,768, p=0,001)$, anne eğitimi ortaokul ve altı olanların $(\mathrm{t}=3,554, \mathrm{p}=0,001)$, annesi ev hanımı olanların ( $\mathrm{t}=2,530 \mathrm{p}=0,012)$ daha düşüktür. Baba eğitiminin son testte toplumsal cinsiyet üzerindeki etkisi kaybolmuştur( $\mathrm{p}>0,05)$.

Toplumsal cinsiyet rolleriyle ilgili tutumları olumsuz bulunan ögrencilerin hem ön testte( $t=-6,3, p=0,001)$ hem de son testte profesyonel tutum puan ortalamaları $(\mathrm{t}=-7,7$, $\mathrm{p}=0,001$ ) daha düşüktür.

\section{Tartışma}

$\mathrm{Bu}$ araștırmada ikinci sınıf tıp öğrencilerinin kadına yönelik şiddetle ilgili bilgi düzeylerinin düşük olduğu ve hem profesyonel rolleri hem de şiddeti gerekçelendirmeyle ilgili tutumlarının istenen düzeylerde olmadığı ortaya konmuștur. Verilen eğitim uzun erimli sonuçları değerlendirmemekle birlikte hem bilgi puanlarını, hem mesleki rollerle ve toplumsal cinsiyet rolleriyle ilgili tutumlarinı olumlu yönde etkilemiștir.

Sağlık çalışanlarının kadına yönelik şiddetteki rolleri yaşamsal bir öneme sahiptir. Şiddet görmüş kadının çoğu zaman başvurduğu yegane kurum sağlık kurumlarıdır. $\mathrm{Bu}$ nedenle çalıştıkları kurumlarda çoğu zaman yönetici rolleri olan hekimlerin bu konudaki bilgi, tutum ve davranışlarının önemi literatürde gösterilmiştir ${ }^{13,14}$. Ne yazık ki tıp fakülteleri müfredatında bu konu su ana kadar yeterince ele alınmamıştır. ABD'de Adalet ve Sağlık Bakanlıkları işbirliğinde yürütülen bir projede tıp fakültelerinin bu konudaki müfredatları incelenmiş ve eksiklikler ortaya konmuştur ${ }^{14}$. Oysa tıp eğitimi sırasında bu konuda özel eğitim almış hekimlerin, kadına yönelik şiddetle ilgili sorgulamaları daha sık oranda yaptığ $\quad$ bilinmektedir ${ }^{15}$. Hacettepe Üniversitesi altıncı sınıf öğrencilerinde yürütülen bir araştırmada, intörnlerin \%70,7'si kadına yönelik şiddeti ele almada yeterli bilgiye sahip olmadığını ve dörtte üçünden fazlası da (\%78.8) kadına yönelik şiddeti ele almanın mesleki uygulamalar içerisinde yer alması gerektiğini bildirmiştiri6.

$\mathrm{Bu}$ çalışmada bilgi puan ortalaması altıncl sınıf tıp öğrencileriyle yürütülen araştırmadakinden düşük bulunmuştur. Yıldız ve arkadaşlarının çalışmasında da bu araştırmada saptandığı gibi kadınların bilgi puanı erkeklerden anlamlı olarak yüksek saptanmıştır ${ }^{16}$. Bu çalışmada, öğrenciler acil serviste çalışan hekimlerin ya da hemşirelik öğrencilerinin aksine kadına yönelik şiddetin tüm sosyoekonomik gruplarda yaygın olduğunu hem ön testte hem de son testte doğru olarak yanıtlamışlardır11,17. Kaynar ve arkadaşlarının araştırmasıyla benzer biçimde ön testte öğrencilerin yaklaşık \%25'i gebeliğin şiddetten koruyacağını bildirmiştir ${ }^{17}$. Ders sonrası bu soruya doğru yanıt verme oranı oldukça yükselmiştir. Öğrencilerin hem öntestte hem de son testte duygusal ve ekonomik şiddetle ilgili bilgi sorularını daha düşük düzeylerde doğru yanıtladıkları gözlenmiştir. Benzer bir sonuç Türkiye'de 1996-1998 yıllarında sağlık çalışanları, polis ve avukatların kadına yönelik şiddetle ilgili hizmet içi eğitim aldıkları bir proje kapsamında hekimlerin eğitim aldıkları bir programın ön değerlendirmelerinde de saptanmiştır'18. Söz konusu projede, hekimlerin eğitim öncesi testlerde konunun gerekliliği ve kadınlara bu konuda yardımcı 
olma durumlarıyla ilgili verdikleri yanıtların, eğitim sonrasında çok değiştiği ve hekimlerin mezuniyet öncesine kadına yönelik şiddetle ilgili dersler konmasını önerdikleri bildirilmiştir ${ }^{18}$.

Kadına yönelik şiddet Türkiye'de yaygındır ${ }^{1,19} . \mathrm{Bu}$ yaygınlık kadının yasal olarak yeterince korunmamasıyla, istihdamda yeterince yer almamasıyla, eğitim seviyesinin düşüklüğüyle açıklanabilmekle birlikte, bu ülkede kadına yönelik şiddetin toplumsal olarak kabul edilen bir davranıs olmasından da kaynaklanmaktadır. Örneğin çok yakın bir zamana kadar namus cinayetlerinin ceza indirimi için önemli bir gerekçe olarak kabul edilmesi buna bir örnektir. Türkiye'de kadınlar yasal düzlemde erkeklerle görece eşit haklara sahip olmakla birlikte, kadın hem kamuda hem de özel alanlarda eșitsizliklere maruz kalmakta, geleneksel roller üstlenmektedir ${ }^{19}$. $\mathrm{Bu}$ durum öğrencilerin profesyonel rollerine de yansımıștır. Öğrencilerin bir kısmı dayağın, haklı bir gerekçesi olduğunda "kabul edilebilir" olduğunu düşünmekte ve mesleki pratiklerinde de kendilerine bununla ilgili rol biçmektedirler. Öğrencilerin sadece \%57,7' sinin ön testte "Şiddete uğramış kadına öncelikle eşini kızdıracak ne yaptığının sorulması gerekmektedir" önermesine; \%34,3'ünün "Şiddete uğradığını bildiren kadının doğru söyleyip söylemediği, kadın eşiyle birlikte dinlenerek anlaşlabilir" önermesine ve \% 57,2' sinin "Şiddete uğramış kadına, tartışmaya yol açan davranışlarda bulunmamasını önererek yardımcı olunabilir" önermelerine, katılmıyorum yanıtını vermiş olması, bu hipotezi desteklemektedir. Kaynar ve arkadaşlarının ebelik ve hemşirelik öğrencilerinin tutumlarını değerlendirdikleri araştırmalarında da aynı sorularda katılmıyorum yanıtını verenlerin oranı sirasıyla $\% 55,9, \quad \% 16,0, \% 41,1$ dir $^{17}$. Tıp öğrencilerinin bu konudaki tutumları daha iyi olmakla birlikte, dikkat edilmesi gereken diğer önemli bir unsur, öğrencilerin bu tür vakalarda kendilerinin bir karar vermesi gerektiğine olan inançlarıdır. Kadına yönelik şiddetle ilgili verilen eğitimlerde buna dikkat edilmeli, şiddetin hiçbir zaman haklı gerekçesi olmadığı vurgulanmalı, hekimlerin hakim olmadıkları ve kişiler arası çatışmayı ancak adli kurumların çözebileceği vurgulanmalıdır. Son testte bu sorulara verilen yanitlar daha olumluya gitmekle birlikte hala azımsanmayacak kadar olumsuz yanit mevcuttur.

Kadına yönelik şiddet dersi profesyonel tutumlarda olumlu değişime neden olmuştur. Bununla birlikte ders sonrasinda da doğduğu bölge ve cinsiyetin daha olumsuz tutuma sahip olmayı etkilemeye devam ettiği görülmektedir. Bunu destekler biçimde toplumsal cinsiyet rollerinin bilgi ve tutum rolleri üzerindeki etkisi ders sonrasında değişmemiştir. Toplumsal cinsiyet rollerinin oluşumunda irdelenen doğum bölgesi ve cinsiyet, anne eğitimi gibi tüm bu değişkenlerin yeri önemlidir. Bir toplumda kadın ve erkeklerin toplumsal hayata katılım biçimi, oranı, görünürlügü ve temsil biçimi önemli oranda o toplumda geçerli olan toplumsal cinsiyet algisından etkilenir. Toplumsal cinsiyet rolleri coğrafyaya, zamana, sınıfa ya da ırka göre olduğu kadar toplumun siyasi ve ekonomik koşullarına göre de çeşitlilik gösterir. Ökten 2009 yılında yayınladığı makalesinde Güney Doğu Anadolu Bölgesi'nde kadınların daha çok aşiret ya da topluma uygun davrandığını, erkek egemen bir anlayış ve tutumun geleneklerden törelere, toplumsal ve bireysel davranışlara kadar geniş bir alanda yansıma bulunduğunu aktarmıştır ${ }^{20}$

Toplumsal cinsiyet rolleri ve algısının kadın lehine değişimi çok daha köklü mücadelelerle mümkündür. $\mathrm{Bu}$ konu tıp fakültelerinde daha yeni tartıșılmaya başlanmıştır. Tıp eğitimine kadına yönelik şiddet ve toplumsal cinsiyet rolleriyle ilgili derslerin eklenmesiyse önemli bir katkıdır. Tıp Fakülteleri Ulusal Çekirdek Eğitim Programı'nda kadına yönelik şiddetle ilgili bir başlık yoktur ${ }^{21}$. Kadına Yönelik Aile İçi 
Tıp eğitiminde kadına yönelik şiddet dersi

Şiddetle Mücadele Ulusal Eylem Planı Madde 2.7'de toplumsal cinsiyet eşitliği ve kadına yönelik aile içi şiddet konularına eğitim, hukuk, tıp, iletişim ve diğer ilgili fakültelerin lisans programlarında yer verilmesi belirtilmektedir. Toplumsal cinsiyet eşitliği ve kadına yönelik aile içi şiddetin önlenmesi konularının müfredat içine alınması için tıp fakültelerine bir yazı gönderilmiş ve 2008 yılından itibaren tıp fakülteleri izlenmeye bașlamıștır22

Bununla birlikte 2003 yılından beri UÇEP'te bir değişiklik yapılmaması nedeniyle, bu durum bir öneri niteliğinde kalmıştır. Genelde tıp fakülteleri müfredatlarında Adli Tıp stajı/kurulu kapsamında "aile içi şiddet" başlığıyla bir saat teorik ders $23,24,25$ veya nadiren "kadına yönelik şiddet" başlığında bir saat teorik ders ${ }^{26}$ şeklinde yer almaktadır

Tıp Fakültesinde pre klinik ve klinik dönemde kadına yönelik şiddetle ilgili verilen eğitimler oldukça etkili olmaktadır. Miller ve arkadaşları tıp fakültesinde klinik öncesi dönemde kadına yönelik şiddetle ilgili eğitim almış öğrencilerin, asistanlıklarında konuyla ilgili yeterlilik düzeylerinin oldukça iyileștiğini göstermișlerdir ${ }^{27}$. Klinik öncesi dönemde verilen eğitimin, sadece olumlu tutum geliştirmeyi değil, yapılandırılmış klinik muayeneyi iyi yapabilme hedefini gerçekleştirmeye de katkı sağladığ literatürde gösterilmiștir ${ }^{28}$. Bunun tersine yayınlar da mevcuttur. Bir araştırmada tıp fakültesi birinci sınıfta verilen üç saatlik eğitimin uzun dönem etkilerinin sınırlı olduğu ve yenilenmesi gerektiği bildirilmiştir ${ }^{29}$. $\mathrm{Bu}$ araştırmanın önemli sınırlılıklarından biri dersin kısa erim sonuçlarının değerlendirilmiş olmasıdır. Ayrıca sadece bir tıp fakültesinin ikinci sınıf öğrencileri değerlendirilmiştir. Bunlar yanı sıra dersi veren hocalar arası fark da tartışılmamıştır. $\mathrm{Bu}$ araștırmanın sonunda derste sunulan olgunun toplumsal cinsiyet rolleri açısından da geliştirilmesine karar verilmiştir. Ayrıca öğrencinin vakayla karşılaştığında adli karar verici olarak davranmasını engelleyecek öneriler geliștirilip profesyonel tutumları olumlu yönde desteklenecektir.

\section{Sonuç}

$\mathrm{Bu}$ araştırma, tıp fakültesi ikinci sınıf müfredatına eklenen bir dersin öğrencilerin hem kadına yönelik şiddetle hem de bu konudaki gelecekteki rolleriyle ilgili bilgi ve tutumlarının geliştirilmesi açısından önemli olduğu ortaya konmuştur. Toplumsal cinsiyete doğum bölgesi, ebeveyn eğitiminin etkileri göz önüne alındığında ve toplumsal cinsiyetle ilgili tutumların sadece şiddet görmüș kadınlara değil tüm hastalara verilen sağlık hizmetinin niteliğini etkileyecektir. $\mathrm{Bu}$ nedenle, toplumsal cinsiyet rolleri ve sağlıkla ilgili ek ders, uygulama ya da modüller, gelecekteki hekimlerin hastalara daha etkin müdahale etmesine yardımcı olacaktır.

\section{Kaynaklar}

1- Altınay AG, Arat Y. Türkiye'de Kadına Yönelik Șiddet. İstanbul: Punto 2 Baskı, 2008.

http://www.kadinayoneliksiddet.org/Tur kiyedeKadinaYoneliksiddet.pdf Erişim tarihi 10 Aralık 2009.

2- Anglin D, Sachs C. Preventive care in the emergency department: Screening for domestic violence. Academic Emergency Medicine 2003;10(10): 1118-1127.

3-Shane B, Ellsberg M. Violence against women: effects on reproductive health. Outlook. 2002; 20(1): 1-8.

4-García-Moreno C, Jansen AF, Ellsberg M, Heise L, Watts C. WHO Multi-country Study on Women's Health and Domestic Violence against Women: Initial results on prevalence, health outcomes and women's responses. Geneva. WHO Press, 2005.

5-Campbell JC. Health consequences of intimate partner violence. Lancet. 2002; 359:1331-1336. 
6- American Medical Association Diagnostic and Treatment Guidelines on Domestic Violence. 1992. http://archfami.amaassn.org/cgi/reprint/1/1/39.pdf Erişim:Mayıs 2011.

7- Whiteman, R. W., Chamberlain, L., \& Greenwood, B.Patients' experiences and perspectives on assessment for lifetime exposure to intimate partner violence and forced sex. Health Alert. Family Violence Prevention Fund.2004.

8-Heise L, Ellsberg M, Gottemoeller M. "Ending violence against women." Population Reports. Series L, No. 11. Baltimore, Maryland: Population Information Program, Johns Hopkins University School of Public Healt,. 1999.

9-Laing L. Australian Domestic \&Family Violence Clearing House. Risk Assessment in Domestic Violence. www.austdvclearinghouse.unsw.edu.au/to pics/topics_pdf_files/risk_assessment.pdf Erişim tarihi: Mayıs 2006.

10-Ganley AL, Fazio J, Hyman A, James L, RuizContreas A. Improving the healthcare response to domestic violence: a trainer's manual for health care providers. Family Violence Prevention Fund.1998. ABD. http://www.fvpf.org Erişim tarihi: Mayıs 2006.

11- Davas A, Aksu F. The Training needs of Turkish emergency department personnel regarding intimate partner violence $\mathrm{BMC}$ Public Health 2007;7:350.

12- Güneș G, Kaya M, Pehlivan C. Tıp Fakültesi öğrencilerinin ailelerinde kadına yönelik aile içi şiddetle ilgili bir araştırma. Toplum ve Hekim 2000; 15(5):391-397.

13-Wathen CN, Tanaka M, Catallo C, Lebner AC, Friedman MK, Hanson MD, Freeman C, Jack SM, Jamieson E, Macmillan HL; McMaster IPV Education Research Team. Are clinicians being prepared to care for abused women? A survey of health professional education in Ontario, Canada. BMC Med Educ.2009; Jun 18;9:34.

14- Confronting Chronic Neglect: The Education and Training of Health Professionals on Family Violence http://books.nap.edu/catalog/10127.html Erişim tarihi Mayıs 2011.

15- Sitterding HA, Adera T, Shields-Fobbs E. Spouse/ partner violence education as a predictor of screening practices among physicians. J Contin Educ Health Prof 2003;23:54.

16- Yıldız AN, Bilir N, Doğan A, Hüseyinoğlu B, Göktaş $B$, Gördük MN, İşgören Ş, İnce 0 , Soytaş M. Hacettepe Üniversitesi Tıp Fakültesi 2010-2011 Öğretim Yılı Dönem Altı Öğrencilerin Aile İçi Kadına Yönelik Şiddet Konusunda Bilgi Düzeyleri Ve Görüşleri. P034. Ulusal Halk Sağlığı Kongresi. Trabzon, 4-8 Ekim 2011.

17-Kaynar Tunçel E, Dündar C, Peşken Y. Ebelik ve hemşirelik öğrencilerinin aile içi şiddet konusunda bilgi ve tutumlarının değerlendirilmesi. Genel Tip Derg 2007;17(2)syf 105-110.

18- Salaçin S. Sağlık çalışanlarının kadına yönelik şiddetin önlenmesinde üstlenebilecekleri roller. www.huksam.hacettepe.edu.tr/.../saglik_c alisanlarinin_kadina_yonelik.pdf Erişim tarihi: Haziran 2011.

19-Buken NO, Sahinoglu S, Violence against women in Turkey and the Role of women physicians. Nurs Ethics 2006 ;13: 197.

20- Ökten Ş. Toplumsal Cinsiyet ve İktidar: Güney doğu Anadolu Bölgesinin toplumsal cinsiyet düzeni. Uluslararası Sosyal Araștırmalar Dergisi Summer 2009; 2( 8) 302-312.

21-Sağlık Bilimleri Eğitim Konseyi. Tıp Fakülteleri Ulusal Çekirdek Eğitim Programı(UÇEP)http://www.aku.edu.tr/A KU/DosyaYonetimi/TIP/pdf/ucep.pdf . Erişim: 19/10/2011. 
22-(T.C.Başbakanlık Kadının Statüsü Genel Müdürlügü. Kadına Yönelik Aile İçi Şiddetle Mücadele Ulusal Eylem Planı 2007 $-2010$.

http://www.ksgm.gov.tr/Pdf/kadinayonel ikaileicisiddetlemucadeleulusaleylemplani. pdf. Erişim: 19/10/2011.

23-Hacettepe Üniversitesi Tıp Fakültesi 20102011 Akademik Takvimi http://194.27.160.122:16080/fmi/iwp/cg i?-db=AcademicCalendar.fp7\&-loadframes, Erișim: 19/10/2011.

24- Adnan Menderes Üniversitesi Tıp Fakültesi 2010-2011 Akademik Takvimi http://www.akademik.adu.edu.tr/fakulte/ med/topics.asp?path=313930, 25- Erişim: 19/10/2011.

25-Celal Bayar Tıp Fakültesi 2010-2011 Akademik Takvimi www.bayar.edu.tr/ tip/belgeler/ 20102011.pdf, Erişim: 19/10/2011.
26- Uludağ Üniversitesi Tıp Fakültesi 20102011 Akademik Takvimi tip.uludag.edu.tr/egitim11/4-sinifzorunlustaj-rehberi.doc Erișim: 19/10/2011.

27- Miller AW; Coonrod DV; BradyMJ; Maricela P. Moffitt MP Medical Student Training in Domestic Violence: A Comparison of Students Entering Residency Training in 1995 and 2001. Teaching and Learning in Medicine, 16(1), 3-6.

28-Haase CE, Short PD, Chapman DM, Dersch SA. Domestic violence education in medical school: Does it make a difference? Academic Emergency Medicine 1999;6:855-7.

29--Ernst AA, Houry D, Weiss SJ, Szerlip H. Domestic violence awareness in a medical school class: 2-year follow-up. SouthMed J 2000;93:772-6. 